\title{
10
}

\section{'Only the best is good enough for eternity': Revisiting the ethnography of T. G. H. Strehlow}

\author{
Jason Gibson ${ }^{1}$
}

In September 2006, I sat with one of the few men still alive who had performed, in 1965, for the films of Theodor George Henry (T. G. H.) Strehlow (1908-78). We watched an hour-long silent colour film that depicted more than 27 different Anmatyerr ceremonies and included the participation of up to 10 individuals. The film had never been publicly screened before and had certainly never been viewed by Aboriginal people in the four decades since its making. I became fascinated with the manner in which films like this had been made and curious as to the intellectual style, theoretical agenda and methodological processes that drove this ethnographic project.

Though plentiful analyses of Strehlow's moral character and his intriguing life abound (Hill 2002; Morton 1993; McNally 1981), there have been very few attempts to interrogate the theoretical influences and motivations that shaped his ethnographic practice. One exception is Philip Jones's

1 Harold Payne Mpetyan, Ken Tilmouth Penangk, Max Stuart Kngwarraye (deceased), Paddy Willis Kemarr, Archie Mpetyan, Ronnie Penangke McNamara, Malcolm Heffernan Pengart and Huckitta Lynch Penangk were particularly generous in their memories of 'Strehlow-time'. I am grateful to the Monash Indigenous Centre and the Strehlow Research Centre for making the fieldwork and archival research for this chapter possible. 
(2004) discussion of the young Strehlow's 'mentors', although this analysis is deliberately contained to the earliest stages of his career. Others have touched on his theoretical framework (Rowse 1992) and some of his contributions to Australian anthropology (Morton 1997; AustinBroos 1997; Dousset 1999; Kenny 2004), but in-depth examinations of Strehlow's methods and achievements as an ethnographer are not particularly well developed. This chapter attempts to combine an overview of Strehlow's theoretical and methodical influences with an assessment of the contemporary usefulness of his singular approach.

First, I begin by examining the absolute commitment to empirical datagathering that characterised Strehlow's ethnographic career over four decades, and which has been described as approaching 'perfection' in its technical execution (Morton 1995: 55). Strehlow operated according to his own program and often deliberately worked to set himself apart (Jones 2004: 36), so zeroing in on his inspiration is not easy. This chapter sketches his general intellectual style and points to some of his influences in Australia, the United Kingdom and Europe. Second, I outline the less widely appreciated regional scope of his inquiries and draw attention to his significant work among the Anmatyerr (a distinctive language and cultural group to the north of the Arrernte). ${ }^{2}$ Third, in the course of discussing this material, I sketch out some of the changes that occurred in Strehlow's theoretical thinking and fieldwork methods over the course of his career and associations with particular intellectual disciplines. And last, I assess the utility of Strehlow's work via the commentaries of the handful of Anmatyerr men still alive who remember working with Strehlow. This reinterpretation of Strehlow's data (the audio and film recordings and field diaries) also demonstrates a tension between particularism and generalisation in his work.

\section{'Preserving' information}

T. G. H. Strehlow's approach to ethnographic record-taking was very much like that of his father, Carl, in that it was humanistic and emphasised mythology, song and language (cf. Kenny 2013). The 44 field

2 The orthography favoured in this chapter is the one currently dominant in most Arandic language communities, including the Anmatyerr communities. It was developed through the work of the Institute of Aboriginal Development (see Dobson and Henderson 1994; Green 2010). Strehlow's original spelling has been included in parentheses following the current spelling. 
diaries produced during his four-decade-long career are replete with some of the most meticulously detailed descriptions of content of this type ever produced. When rereading the original field diaries, listening to the song recording or viewing the films produced by Strehlow over his career, one is struck by the tremendous commitment to documenting not only the particularities of Central Australian languages, mythologies and songs, but also their interrelationships and sophistications.

Strehlow's emphasis on empirical documentation has, thankfully, made his work amenable to reinterpretation and reanalysis by interested researchers and has provided further avenues for re-engagement with the material (Gibson 2015; Kenny 2004; Morton 1997). There are, however, stumbling blocks. The majority of the film and song recordings made by Strehlow contain ceremonial content of a secret-sacred nature, and thus access is nominally reserved for those who can demonstrate significant cultural rights to the material. These restrictions, coupled with the fact that detailed cataloguing of the film and song recordings has been completed only in recent times, have meant that the extensive audio and filmic collection has been largely inaccessible to researchers and Central Australian Aboriginal people. As a consequence, analysis of both the contents of these recordings and the context of their production has been incredibly limited.

The personal biography of T. G. H. Strehlow, complete with analyses of his personality and upbringing (Morton 1995, 2004; Hill 2002) and the later controversies surrounding the handling and ownership of his collection (Kaiser 2002; Smith 2009), has largely overshadowed discussions regarding his legacy and influence in anthropology. Barry Hill's (2002) dense and compelling narrative of Strehlow's life, for example, never seriously engages with Strehlow as an ethnographer and therefore glosses over the incredibly significant changes that occurred in not only his methods, but also his engagement with anthropological theory. This focus on the personality of Strehlow has obscured not only the dialogical properties of the ethnography and its relevance to contemporary Arandic ${ }^{3}$ lifeworlds, but also, as Michael Jackson (2003: 88-9) has pointed out, its wider social and historical influences.

3 Arandic languages are a subgroup of Australian languages consisting of two dialect clusters, Arrernte and Kaytetye (Koch 2006). Anmatyerr is a part of the Arrernte dialect cluster. 


\section{Strehlow's intellectual style}

An appreciation of Strehlow, and the fiction of who he thought he was in the field, is, of course, important to understanding this collection. Strehlow (1950: 129) described himself as being 'trained by natives' and not by 'armchair anthropologists', and his very personal, long-term and deep attachment with his region of study was uncommon in Australia at the time (Hinkson and Beckett 2008: 7). Strehlow approached his research in a way that may have resonated with his contemporary, the American sociologist C. Wright Mills. Mills (2000: 215) wrote that 'the individual social scientist' working in the 'classic tradition' sees their effort as the 'practice of a craft'. They are 'made impatient and weary by elaborate discussions of method-and-theory-in-general', as it 'interrupts' their 'proper studies' (Mills 2000: 215). Working from a similar premise, Strehlow's ethnography was undoubtedly a serious personal obligation. This intense focus led to a proprietorial attitude that ultimately intimidated many other researchers interested in conducting either linguistic or anthropological studies within the Arandic region (Green 2001: 33-4; Hill 2002: 336; Marcus 2001: 111).

Having grown up with knowledge of his father's work and later trained in English literature and the classics, Strehlow gradually became committed to the idea of ensuring that Central Australian oral literature was regarded as an equal to the poetry and literature of Europe's past. He studied Latin and Greek in his undergraduate years and emerged from Adelaide University with first-class honours in English. Under the tutelage of Professor Archibald Strong, the author of an acclaimed translation of the Anglo-Saxon poem Beowulf, Strehlow's keen interest in the literature and mythologies of Europe matured. Thus, with his feet firmly planted in the traditions of the Old World, Strehlow turned his mind to postgraduate studies and, under the careful guidance of professor of classics John Aloysius FitzHerbert (1892-1970), he devised a master's research proposal that went on to shape the remainder of his academic career.

In hindsight, Strehlow's MA thesis proposal looks like an early sketch of the themes that came to dominate his most significant work, Songs of Central Australia, published more than 40 years later. The proposal outlined an examination of the 'Primitive elements in Old Icelandic mythology and in Old English heroic verse, in the light of Aranda myths 
and legends' (Hill 2002: 121). ${ }^{4}$ Given that Strehlow was only in his 20 s at the time, and had not been to Central Australia since he was 13, we can only assume that his knowledge of these 'Arrernte myths and legends' came primarily from his father's work, Die Aranda- und Loritja-Stämme in Zentral-Australien. ${ }^{5}$ In these formative stages of his fieldwork career, T. G. H. also found guidance from a number of individuals associated with the University of Adelaide's Board for Anthropological Research, including Professor John Burton Cleland, Dr Thomas Draper Campbell, Henry Kenneth Fry and Norman B. Tindale (Jones 1995; Strehlow 1932: 203). As explained below, his first episode of fieldwork research in the Anmatyerr region was interrupted by his brief role in locating and encouraging Pintupi people to attend the Board for Anthropological Research expedition team at Mt Liebig (see Batty 2013).

Strehlow's intellectual engagement with anthropology was undoubtedly secondary to his training in literature and languages (Jones 2004: 37; Ronald Berndt, in McNally 1981), and, despite a number of publications firmly within the discipline, he found himself largely on the peripheries of mainstream Australian anthropology (Austin-Broos 1997: 51). What social anthropologist John Barnes described as Strehlow's 'odd frame of reference' left those in mainstream Australian anthropology perplexed (Barnes, in Gray 2007: 224). Raymond Firth, too, struggled to comprehend Strehlow's approach and, despite publicly acknowledging T. G. H. as the son of a 'famous father' (Strehlow 1950: 165) and thus part of an Australian anthropological lineage, he paid scant attention to his early manuscripts for Songs of Central Australia.

Strehlow strove for a detailed record of the linguistic, mythological and symbolic repertoires of Central Australians, and fitting this material into the conceptual apparatus of social anthropology was mostly a secondary concern. Ethnographic fieldwork, he argued, was at the heart of all worthwhile research and led to the gathering of 'stubborn and intractable' 'facts' that would 'outlive and outlast all theories' (Strehlow 1969: Vol. 15, no. 2, p. 1). 'Isn't it the field workers that matter', Strehlow (1968: 80)

\footnotetext{
4 This thesis never came to fruition. Instead, he submitted a thesis in linguistics that was later published as 'Aranda phonetics' (Strehlow 1942).

5 The focus on heroic verse in old European and Arrernte traditions had obvious resonances with Frazer's comparative analysis of world mythologies; however, it was not until 1949 that mythologist Joseph Campbell published his influential The Hero with a Thousand Faces.
} 
asked rhetorically during one of his later trips in the Anmatyerr region. ${ }^{6}$ This commitment to 'facts', rather than being interpreted as a complete rejection of theory, should rather be seen as positing that all theory 'must hover close to and emerge from data' (Hedican 2009: 424). Of course, the notion that 'facts' can be discovered via 'dutiful empiricism' (Geertz 1961) has been heavily criticised in anthropology. Strehlow's 'facts' were, of course, assembled within a conceptual framework characterised by a nostalgic longing for an Arandic past, and a blinkered commitment to the documentation of ritual and song.

\section{Continental connections}

Despite some speculation that Strehlow-either via his father or independently - found inspiration from a distinctively German-speaking tradition in anthropology (Austin-Broos 1997: 54), there is no direct link in Strehlow's corpus to either the German romantic tradition of the nineteenth century or the Boasian school. While Strehlow may have read Johann Gottfried Herder at some stage in his life, as Hill (2002: 23) suggests, there is little to indicate that this had any significant influence on him. ${ }^{7}$ Nor is there evidence of influence via American anthropology, although things may have been different had Strehlow, as was suggested by Raymond Firth in 1932, travelled to Yale to receive training from Edward Sapir (Jones 2004: 37).

Strehlow's methods do nevertheless share some of the key accents typically attributed to German-speaking approaches, such as an emphasis on the detailed observation and documentation of local languages, myths and beliefs. He also committed to learning from one's informants and letting the findings emerge from extended periods of fieldwork. Observing the methods of German Lutheran missionaries (such as his father) translating and working in local vernaculars also affected his orthography for the Arrernte language, his method of genealogical record-keeping and his translation of myth and song. Both T. G. H. and Carl Strehlow in fact relied on a similar approach to linguistics that was influenced by Wilhelm

6 He had already been busy mapping sites along the Stuart Highway in South Australia. Before this, he had been obtaining mapping information and songs from Wangkangurru and Lower Arrernte speaker Mick McLean in Port Augusta.

7 There is no mention made of Herder in either Strehlow's published works or his diary. There are no copies of any Herder text in his personal book collection held at the Strehlow Research Centre in Alice Springs. 
von Humboldt and the classicist Georg Curtius (Moore 2008, and cf. 2003). These methods were generalist, fieldwork-friendly and had been embraced by the Neuendettelsau Mission Society, where Carl Strehlow was trained.

There were other German-speaking ideas, however, that came to occupy an important place in Strehlow's thinking. The allure of psychoanalysis, with its links to studies in comparative mythology, is particularly recognisable in Strehlow's published and unpublished works. As a young master's student, he read a German edition of Freud's Totem and Taboo (1922) and avidly worked through Géza Róheim's Australian Totemism (1925). Róheim's contributions to the International Journal of Psychoanalysis (1932) were also heavily annotated by Strehlow. ${ }^{8}$ References to Carl Jung in the introduction of Strehlow's first book publication, Aranda Traditions (1947: xv), and his stated interest in the possible 'parallels' between Central Australian traditions and those of past European societies reveal a sincere interest in prospects of psychoanalytic theory.

His song data, too, he later claimed, demonstrated not only the possibility of a commonality of human emotions, but also 'uninhibited subconscious drives' (Strehlow 1971: xvi). Although careful not to make definitive statements in support of psychoanalytic theory, he did, however, conclude that, from the type of comparative analysis offered in Songs of Central Australia, 'new light may eventually be thrown on the real reasons for the existence of the parallels', and 'even on the process of human thinking itself' (Strehlow 1971: xl). Unlike his father, who was advised against delving into parallels with European traditions (Kenny 2013: 121), T. G. H. felt freer to entertain comparative and theoretical investigations. ${ }^{9}$

Strehlow maintained his links with German-speaking ideas and academics throughout his career. As early as 1936, he was contacted by representatives from the Frobenius Institute who were already familiar with the work of Carl Strehlow about the possibility of assisting with their planned expedition to Australia (Beinssen-Hesse 2004). Though the Frobenius Expedition (1938-39) ended up travelling to the Kimberley

8 See Strehlow's personal library collection at the Strehlow Research Centre in Alice Springs. The inside cover of the International Journal of Psychoanalysis (vol. XIII, 1932) reads: 'T. G. Strehlow June 25th 1933, Alice Springs.'

9 Others influenced by comparative mythology, psychoanalysis and cultural diffusion, such as the American mythologist Joseph Campbell, also received some support from Strehlow (Campbell 1974: xii, 185). 
region of Western Australia, contact with what Gingrich (2005: 108) has described as the 'late-Romantic', 'speculative' and yet 'fieldwork-oriented' school of cultural morphology continued. Most notably, Strehlow contributed to the Festschrift of Adolf Ellegard Jensen (Schuster et al. 1964) and received encouragement from Helmut Petri, whom he met with in London and Frankfurt in 1950 (Strehlow 1950: 130). ${ }^{10}$

\section{A collection of regional scope}

Perhaps one of the biggest misconceptions about Strehlow's ethnographic collection is that its contents pertain almost exclusively to the Arrernte. This emphasis on Arrernte and, more specifically, Western Arrernte material has almost certainly emanated from the largely biographical approach to Strehlow's corpus with his ties to the Hermannsburg Mission and the status of his father, Carl. Most analyses of Strehlow's anthropological material have accordingly focused on this Western Arrernte content (Morton 1997; Austin-Broos 2004, 2009) and overlooked material from other language or cultural groups. For example, when I first came to specifically explore the extent of the Anmatyerr collections at the Strehlow Research Centre close to 10 years ago, I discovered that the genealogies of over 370 Anmatyerr individuals were absent from the listings used by Aboriginal clients and other researchers visiting the centre. ${ }^{11}$ The presence of Anmatyerr-related ceremonial objects, films, song recordings or documents was also incorrectly denied. ${ }^{12}$

A purely quantitative analysis of the Strehlow collection reveals the limitations of these past analyses. Although there is undoubtedly a very significant amount of Western Arrernte material in Strehlow's collection, the Eastern Arrernte content slightly outweighs it and the Southern, Central and Northern Arrernte material is also extensive. Crucially, Strehlow also made extremely significant recordings of both Anmatyerr and Luritja songs and ceremonies as well as far smaller collections of Alyawarr and Wangkangurru material. In the Anmatyerr area alone, more than 55 individuals (mostly men) acted as informants, guides or

10 Strehlow also wrote a favourable review of Andreas Lommel's 'humanitarian' and 'emotional' Fortschritt Ins Nichts (see Strehlow 1970a).

11 Anna Kenny has, however, in recent times included the Anmatyerr genealogies in her research (2013: 219).

12 I first began looking into the possibility that Strehlow had collected Anmatyerr sacred objects at the behest of the late Don Campbell in March 2006. 
performers over four decades of research. Many hours of recordings were made of Anmatyerr songs and well over 150 song texts were transcribed. ${ }^{13}$ Close to 50 different ceremonial 'acts' from across the length and breadth of the Anmatyerr region (approximately 4,000 square kilometres of the Northern Territory) were filmed and photographed in colour (Strehlow 1971: xiv, xx) and Strehlow's field diaries contain detailed maps of the 'totemic geography' for the region. In addition to this anthropological material, the diaries also contain important social histories of early Anmatyerr interactions with Europeans and thus undoubtedly comprise the most voluminous and important ethnography of the Anmatyerr prior to the land rights era (beginning in about 1975).

Though undoubtedly Arandic in linguistic terms, the Anmatyerr have a distinctive social and cultural history that differs from their neighbours to the south, the Arrernte. While the Arrernte region has been, at least in part, shaped by a history of two competing missions (Catholic in the east and Lutheran in the west) and an expanding township (Alice Springs) at its centre, the Anmatyerr region has never hosted a sizeable township, mission or government settlement and has instead been characterised by a long-term engagement with pastoralism. ${ }^{14}$ Anmatyerr familial and cultural links with the Warlpiri to their west, as well as their strong links with the Alyawarr and Kaytetye, suggest that Strehlow's work in this region be considered in its own right and not subsumed within an analysis of his Arrernte work.

The following sections explore the nature of Strehlow's work with Anmatyerr people over four decades. By drawing out this history of ethnographic exchange and encounter, I hope to reveal more about Strehlow's changing methods and influences.

\section{Fieldwork transformed}

T. G. H. Strehlow's fieldwork career began with a journey north from Alice Springs into Anmatyerr country in the winter of $1932 .{ }^{15} \mathrm{He}$ was 24 years of age at the time and, armed with his humanistic and philological

13 Catherine Ellis used many of these Anmatyerr song recordings in her groundbreaking dissertation on Central Australian songs.

14 The ration depot at Bullocky Soak, near Central Mount Stuart, was very small and short-lived (between 1945 and 1947).

15 Strehlow first wrote 'Unmatjera' and revised his spelling to 'Anmatjera' in 1968. 
outlook, he set out to ascertain the boundaries of what would later be defined as the Arandic 'language-dialect complex' (Hale 1962), which included the different kinds of Arrernte, Kaytetye, Pertame, Alyawarr and Anmatyerr. By leveraging his personal association with the Western Arrernte and enlisting the critical assistance of the skilled Northern Arrernte interpreter and go-between Tom Ljonga, Strehlow found Anmatyerr people were eager participants in his recording and documentation work. It was with these various Anmatyerr and Arrernte informants that his eyes were first opened to the storied landscape and the ritual cosmology of Central Australian people.

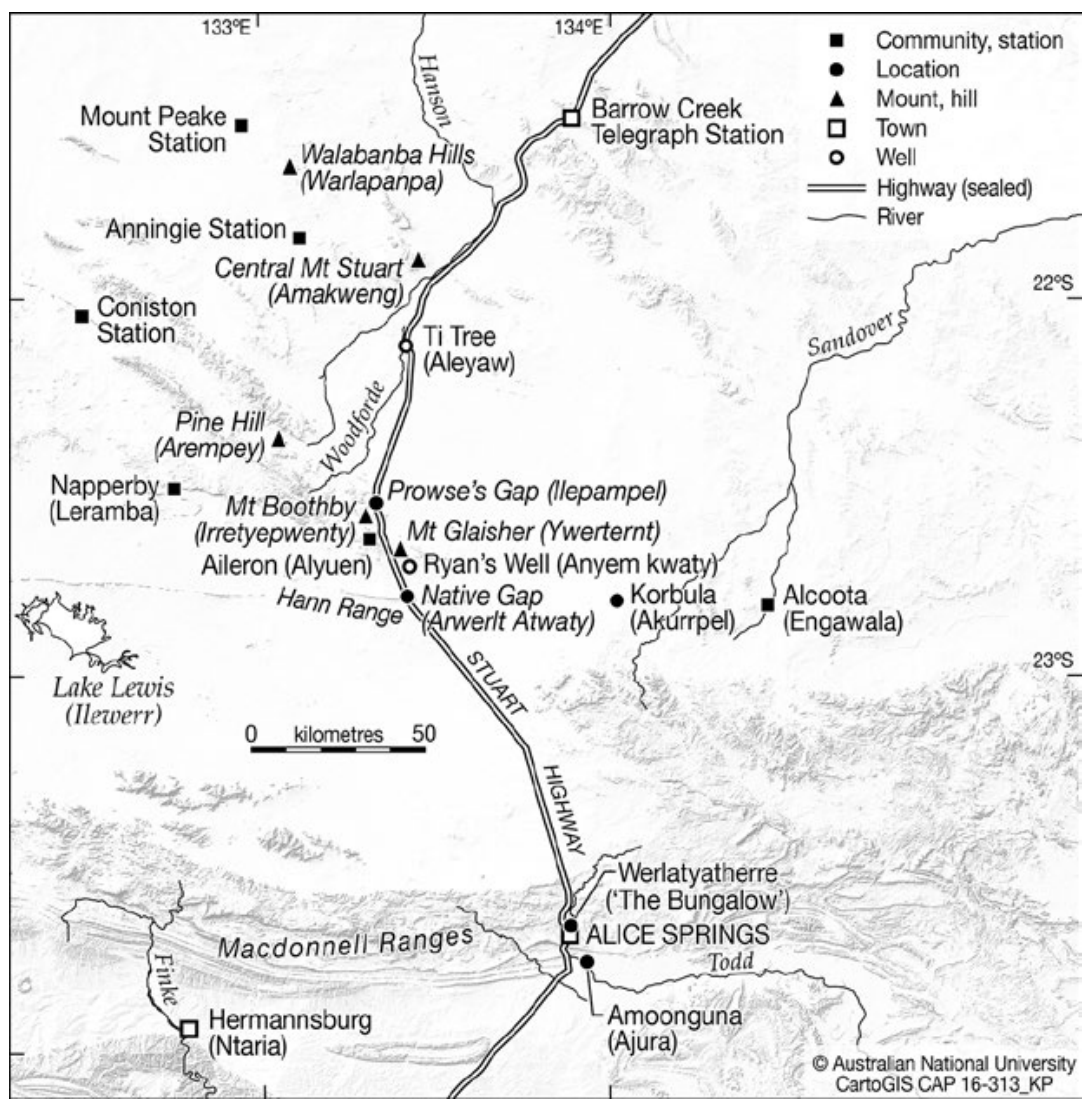

Map 10.1 The area north of Alice Springs where Strehlow worked.

Source: CartoGIS, The Australian National University. 
This fieldwork expedition-what he called the 'Northern Trip'-took him to the far north-western corner of the Anmatyerr territory and along its northern and eastern boundaries. It was here he recorded his very first song verses, collected his first tywerrenge (tjurunga: 'sacred') objects and encountered men with whom he was utterly unfamiliar, but who were nevertheless willing to trade their ceremonial material (see Strehlow 1932). Following a brief diversion from his own research to assist with the University of Adelaide's expedition to Mt Liebig (see Batty 2013), Strehlow immediately returned to Anmatyerr territory, eager to resume his own studies. What he later called the 'Round Trip' began at Napperby Station and followed the perimeter of the Anmatyerr region from west to east (Strehlow 1932: 88). Wordlists, mythologies, song texts and translations were accrued along the way. These two month-long expeditions in Anmatyerr lands, coupled with his time in Arrernte, Luritja and Pintubi territories in 1932, were absolutely critical to Strehlow's understanding of the inherent connection between mythologies, people, landscape and ancestral beings across linguistic or cultural divides.

It wasn't until 1953, over 20 years later, however, that any significant Anmatyerr-related material was again documented. This was the beginning of a new period in Strehlow's research, following two years studying social anthropology at the London School of Economics (LSE) and a brief and yet very successful tour of Europe. Despite his aversion to British social anthropology, Strehlow's research during and after this period in London began to incorporate social anthropological ideas and he became increasingly interested in cultural geography (Strehlow 1952: 1).${ }^{16}$ While Morton (1997: 107) may be correct in surmising that Strehlow felt pressured to adopt some of the language and conceptual apparatus of the functionalists, he nevertheless did adopt this language on numerous occasions (see, for example, Strehlow 1956, 1970b, 1997). As exemplified by his numerous visits to the Assyrian, Egyptian and Greek collections at the British Museum, Strehlow's interest in the classics, however, continued to be his primary source of intellectual stimulation. His audio and film recordings of song and ceremony also remained central to his project even though they were less than enthusiastically received by those at the LSE (Strehlow 1952: 71a-5). In Austria, Belgium, Switzerland, France and Germany, however, his films were given the respect they deserved (Hill 2002: 484).

16 Morton (1997: 107) suggests that he may have been 'pressured' into using these social anthropological theories. 
Admitting that he was 'set in his ways' and that he detested 'both the sort of linguistics and the sort of social anthropology' 'of the functional type' being taught in London, Strehlow (1950: 121, 154) desperately wished to return to his fieldwork and continue his recordings. Returning to Australia in the early 1950s, Strehlow changed his research methods somewhat and began to adopt what were then revolutionary audio and visual technologies such as colour film, colour slide photography and wire audio recording. As 'new ways of preserving this material had been perfected', he later commented, 'it was now possible to take good colour movies of the ceremonial "acts" (performances) and wire recordings of the songs and myths' (Strehlow 1964a: 110). This period of fieldwork (between 1953 and 1962) was also characterised by the staging of ambitious ceremonial 'festivals' in proximity to the Aboriginal settlements in Alice Springs. While Arrernte traditions remained the central focus of the festivals, interlinked Anmatyerr, Luritja, Alyawarr and Pintubi ceremonies and songs were increasingly introduced. ${ }^{17}$

As each ceremony was performed, Strehlow gave it a number, filmed it, photographed it, wrote up a description of the ritual paraphernalia and, in many cases, produced detailed 'film scripts' of the ceremonies. His methods of documentation were being carefully perfected so as to be as thorough as possible.

\section{Revisiting the fieldwork}

The filmic, photographic and audio recordings made during these festivals have in recent years been digitised and are now regularly accessed by Aboriginal men with personal connections to the material. Foreshadowing the uses of this material, anthropologist John Morton noted some time ago that the collection suited 'a new generation of researchers' wishing to 'breathe life' into the 'once dormant' collection via its 'collaborative opening up'. This collaborative rereading of the collection, Morton (2004: 46) suggested, would be most fruitful when it combined 'Aboriginal and anthropological investigations'. As indicated at the beginning of this chapter, it is exactly this experience that sparked my initial interest in the Strehlow materials. The memories and perspectives of Aboriginal people implicated in this wideranging regional ethnography

17 Particularly in 1955 when Bob Rubuntja planned the staging of honey-ant performances linking the Pintubi and Alyawarr populations. 
not only make an important contribution to our understanding of their role in the production of this corpus, but also reveal new perspectives on Strehlow's methods.

A number of Anmatyerr men now aged in their 70s and 80s to whom I have presented some of this material remember witnessing Strehlow's 'festivals' in Alice Springs. One man, Paddy Kemarre Willis, who was in his 20s at the time, remembers Anmatyerr people-from as far afield as Coniston Station (to the north-west) and the Sandover River areas (to the east)_performing for Strehlow's cameras in 1955. These 'high school'18 festivals, he remembered, had been organised and choreographed by senior Arrernte men but many of the participants had been sourced from the general itinerant Aboriginal population in Alice Springs. These people often resided on Aboriginal settlements, either at 'The Bungalow' (between 1953 and 1955) or at the Amoonguna settlement (in 1960 and 1962).

Willis and other Anmatyerr men with whom I have discussed Strehlow's films have noted the opportunistic nature of Strehlow's documentation during these Alice Springs festivals. One of the principal Anmatyerr performers in Strehlow's recordings, a man simply identified as Kwetyaney (Kutjania) by Strehlow, is well remembered by many in the contemporary Anmatyerr community. ${ }^{19}$ Local histories tell us (and are confirmed in Strehlow's notes) that Kwetyaney belonged to the Warlapanpa estate (over 300 kilometres to the north-west of Alice Springs) and was resident at The Bungalow in 1953. Furthermore, Kwetyaney would have been in his early $50 \mathrm{~s}$ at the time of the recordings and, contrary to the conventional narrative, he and other Anmatyerr participants were not driven by the need to see their traditions preserved. They had not, as is often assumed, chosen Strehlow as a 'guardian' of their ritual material (see Jorgensen 2010). Instead, these men had found themselves caught up in an ethnographic project largely outside their immediate concerns. Kwetyaney, and many of the other Anmatyerr men who feature in Strehlow's films at this time, were roving labourers or stockmen and their involvement in Strehlow's project was often unanticipated and opportunistic. ${ }^{20}$

18 The term 'high school' has been adopted by some Central Australian Aboriginal people to refer to the educational aspects of traditional ceremonial practices where knowledge of 'Dreamings', songs and other aspects of religious life were taught to young men during religious festivals.

19 Strehlow writes this name as 'Kutjania' and the estate name as 'Walabanba'. Kwetyaney was widely recognised and remembered as a man of the Ngal subsection who had, in later life, lived at Anningie Station and the Warrabri settlement.

20 Audio File: Paddy Don 10092013 (10 September 2013). 
Anmatyerr descriptions of Strehlow's participation in these 'festivals' also complicate the otherwise tidy narrative of Strehlow as an ingkarte (ingkata) - a boss or leader of Arrernte ceremonies. ${ }^{21}$ On the whole, Strehlow is remembered by those with whom he worked or who encountered him as a privileged documenter of men's ceremonial life in the region and commonly referred to as an 'urrempele-man', meaning someone connected with a series of travelling ceremonies that move across Central Australia. Bob Rubuntja, one of Strehlow's most significant informants in the 1950s, also pointedly referred to Strehlow as akiw-arenye, meaning someone belonging to or inhabiting the ceremonial ground (Strehlow 1953: 50), not someone leading or controlling it. These are important semantic differences seemingly deployed to denote a common category of inclusion or membership in ceremonial activity, but they equally emphasise Strehlow's role as a documenter. The urrempele-man appellation, too, given its reference to regional peregrinations, highlights an awareness of Strehlow's aim to detail the connections between dreaming stories, estates, people and sites. Indeed, it was this attentiveness to the interconnectivity in the storied landscape that continued to drive his research outside the Arrernte area and into the Anmatyerr (Luritja, Warlpiri, Alyawarr, Kaytetye, and so on), particularly in the later half of the 1950s and until the early 1970s.

\section{Recollections of the final years}

The systematic methods of documentation that were developed during the 1950s were continued in Strehlow's final fieldwork period (1964-74); however, the staging of large-scale ceremonial festivals was abandoned. In its place came the fuller documentation of traditions that were linked to particular estates, as well as concerted efforts to map totemic sites and anyenhenge section areas across much of Central Australia. It was also during this time that Strehlow returned to the Anmatyerr region, at the request of Mick Werlaty (Wolatja), an Anmatyerr elder in his 70s. Werlaty had initially approached Strehlow for help in protecting the site of Akurrpele (Korbula) from the construction of a road (Strehlow 1964b: 49-50). Despite being 'sympathetic' to Werlaty's pleas, Strehlow admitted

21 Ngkart appears to be a distinctively Western Arrernte term that has now been adopted into Anmatyerr, although is used almost exclusively to refer to Christian missionaries. The term was never recorded by Spencer and Gillen, who alternatively use what is most likely the Eastern Arrernte variant, Alartetye (Alatunja), which carries a similar meaning (see Wilkins' glossary to Gillen et al. 2001). 
that he felt powerless to act; however, the following year he returned with a proposition to protect the site in the only way he knew how: by filming its ceremonies and recording its songs.

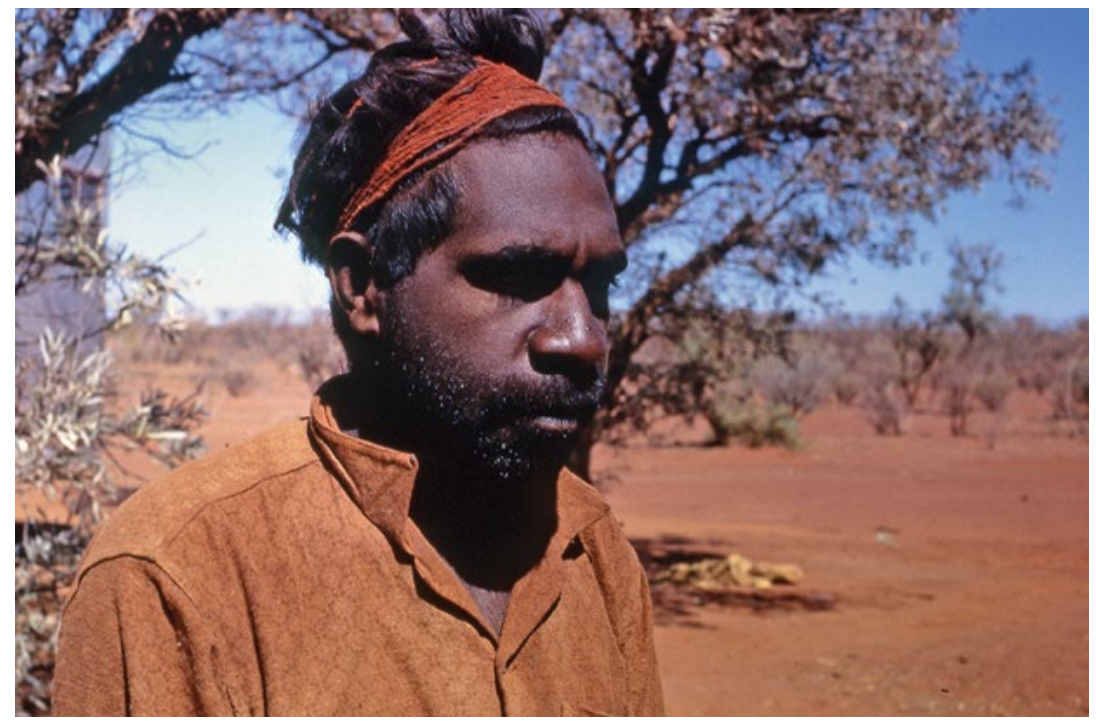

Plate 10.1 Ken Tilmouth Penangk, photographed by Strehlow at Alcoota in 1965.

Source: SRC 03707, Strehlow Research Centre, Alice Springs.

The films that were produced during an intensive five-week period document over 28 separate performances from what Strehlow described as an 'inner cycle'. The Akurrpele films, along with 225 recorded verses, the hundreds of pages of fieldnotes, 140 photographs and the 32 ceremonial objects collected, constitute what is possibly the most complete document of a single estate ever produced in Australia. ${ }^{22}$ Ever striving for the most comprehensive and best-quality recordings possible, Strehlow wanted to create a collection that would endure. 'Only the best is good enough for eternity', he declared when working with the same group again three years later (Strehlow 1968: 58). Werlaty's son, Ken Tilmouth, was in his late $20 \mathrm{~s}$ at the time of these recordings and remembers performing in front of Strehlow's cameras. In recent years, Tilmouth has spent considerable time with staff at the Strehlow Research Centre effectively completing some of Strehlow's work. Using the extensive descriptions provided by

22 See Strehlow catalogue listing spreadsheet at the Strehlow Research Centre, Alice Springs. 
Strehlow in his field diaries and Tilmouth's own first-rate knowledge of the Akurrpele ceremonies, individual song recordings have now been matched to the specific segments of silent colour film footage. ${ }^{23}$

The hubris that came to dominate Strehlow's later career not only blinkered his interpretation of these exchanges, but also limited his appreciation of the prospects for collaborative research of this kind. Instead, he arrogantly claimed to be the sole heir and possessor, not only of the ritual objects presented to him by the men at Alcoota, but also of the ceremonial designs, songs and stories (Strehlow 1965: 8-10, 48). Tilmouth recalls the exchange differently. While his father had presented the ceremonial cycle for Strehlow's documentation purposes, it had been simultaneously and unambiguously shown for the edification of all the men present. ${ }^{24}$ Strehlow's presence, Tilmouth posits, while being a catalyst to stage the ceremonies, was in no way a prerequisite for its occurrence or persistence. The older men had not, as Strehlow imagined, shared this material with him simply because they were sceptical of their sons' abilities to safeguard these customs, but had recognised a new and changing context in which this symbolic labour could be organised and legitimated. Similar Aboriginal responses to the 'new all-inquiring, all-encompassing world' of intercultural relations have been noted elsewhere in Central and Western Australia (Anderson 1995).

The ongoing centrality of tywerrenge ownership and ceremonial life within a changing social, political and cultural context is something that Strehlow chose to either ignore or give only cursory attention to. The changed political context of the 1960s did nevertheless affect Strehlow's practice. The social and political upheaval of the late 1960s and early 1970s produced a period of estrangement between anthropologists and Aboriginal people in Australia (and in most other colonial societies) and led to a new unwillingness among Aboriginal people to play the passive object of study any longer (see Starn 2011: 183-4; Gray 2007: 226-7). An instance of this changed attitude is observable in Strehlow's interactions with these Anmatyerr men at Alcoota in 1968.

23 Interview with Ken Tilmouth at Alcoota, NT, 4 June 2014.

24 Alcoota notes, 15 August 2013. The Arrernte man was Sandy White Penangke, who married into the Anmatyerr/Kaytetye region. 


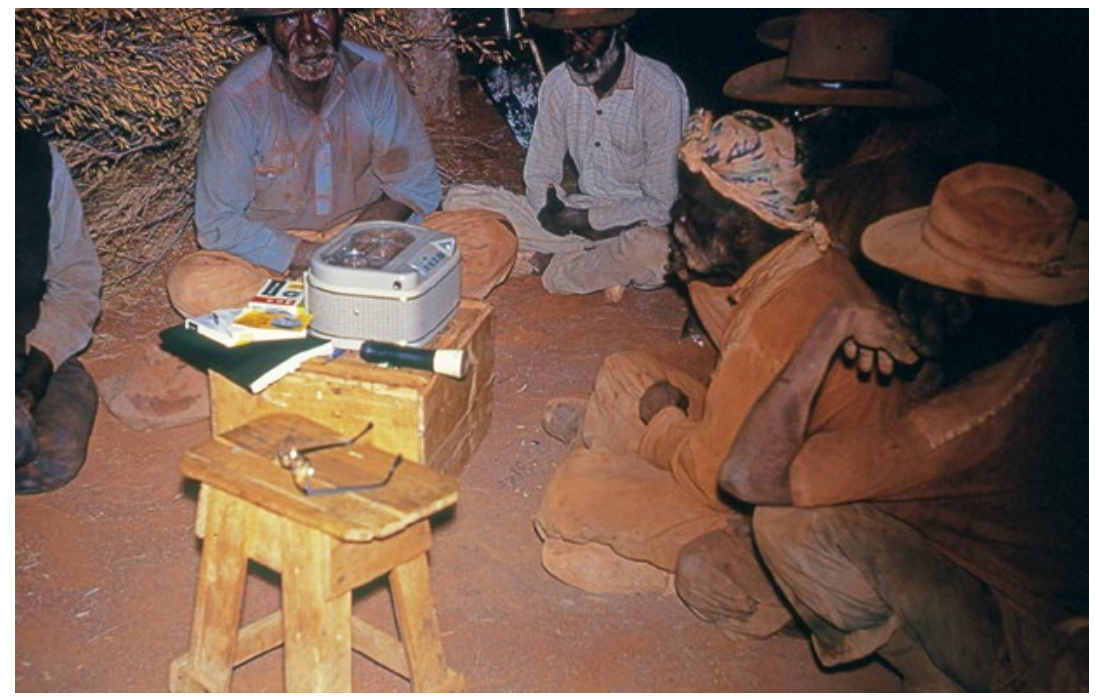

Plate 10.2 Singers gathered around T. G. H. Strehlow's tape recorder at Alcoota in 1965. The man immediately behind the recorder is Mick Werlaty Pengart.

Source: SRC 0370, Strehlow Research Centre, Alice Springs.

Strehlow had arrived at the 'native camp' at Alcoota Station just as a truckload of Anmatyerr men from Napperby Station were on their way to begin staging a circumcision (apwelhe) ceremony. Werlaty quickly reminded Strehlow that as soon as the 'singing began' for these ceremonies, he and his cohort would be obliged to devote all of their attention to the initiation rituals, regardless of Strehlow's desires (Strehlow 1968: 101, 111-14). Recently instituted improved wages for Aboriginal cattle station labour had at this time (1968) led to increased ownership of vehicles and increased mobility, and across the region there was greater intercommunity attendance for initiation ceremonies (see Peterson 2000; Curran 2011). The initiate and a large group of Anmatyerr men from Napperby arrived in their so-called red truck, ${ }^{25}$ and other Anmatyerr people from the north were also making their way in a mixture of station and privately owned vehicles.

25 It is not clear whether this truck was in fact red in colour or whether the name indicated its dangerous cargo - that is, men on restricted ceremonial business. 


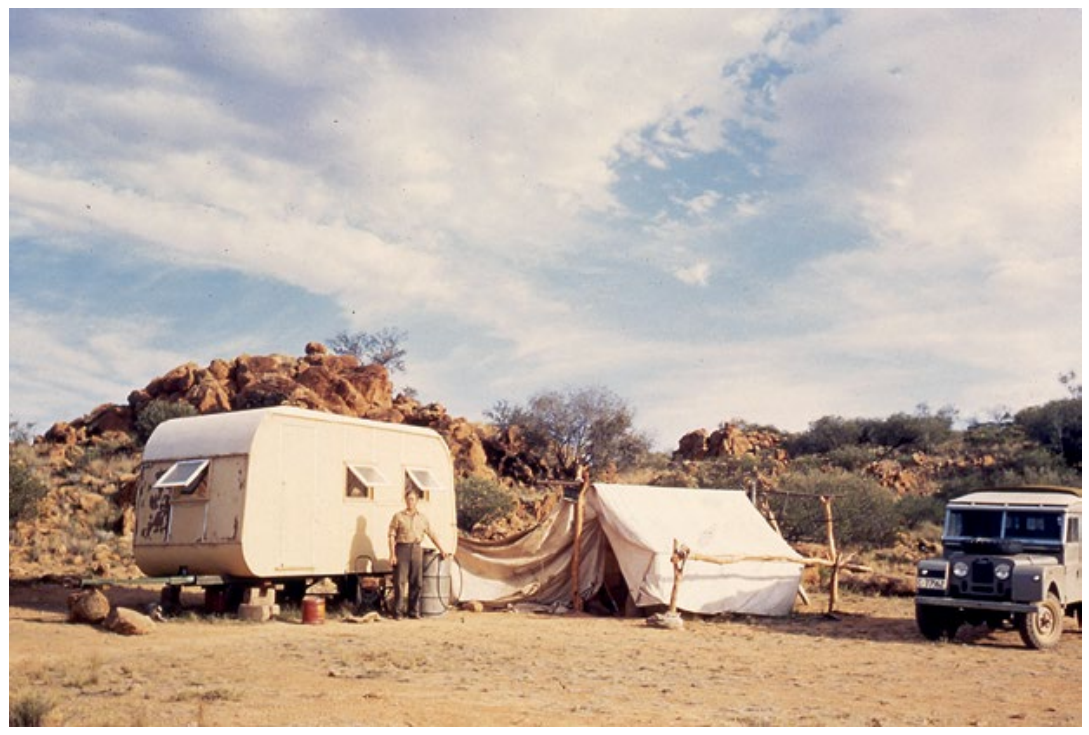

Plate 10.3 T. G. H. Strehlow at Wolatjatara camp, 6 October 1953.

Source: SRC 00812, Strehlow Research Centre, Alice Springs.

Rather than noting the affects of a changing economic and social context on ceremonial life, Strehlow instead fumed that he had for the first time 'been disowned as ingkata [ingkarte] by a section of the Arandaspeaking population' (Strehlow 1968: 114-15). Strehlow's diaries remain silent on the significant social, economic and political changes and their influence on ceremonial practices. Indifferent and perhaps theoretically inept, he failed to grasp social change. The European bourgeois notions of spirituality and sacredness that produced an 'etherealised and aestheticised' conceptualisation of Aboriginal culture (Jackson 2003) failed to grasp the conditions of mundane social existence. It was the 'choice of classical forms', Darren Jorgensen (2010) has argued, that ultimately condemned Strehlow's work to the 'vagaries of the arts in Western culture' that eulogise the past.

These failings do not, however, dominate Anmatyerr memories of Strehlow. Instead, he is discussed as an ethnographer of exceptional skill, particularly when documenting song. 


\section{Remembering his methods}

Reviewing the song and filmic material produced during this final period has also led to a better appreciation of Strehlow's methods. Harold Payne Mpetyan, for example, recalls Strehlow's excellent memory skills and his talents as a singer of Arrernte verse:

He could talk Arrernte language and he could sing, too. Ken and me bin hear him that one. He was singing. We all bin there. Three blokes. He would sing, too [with us], ya proper really one that bloke! [He sang] That apmwa ikwelengk ['king brown snake'] song now. ${ }^{26}$

Harold went on to note that on at least two occasions Strehlow stopped the two men to correct them. Strehlow's diary remains silent on this exchange, but Harold distinctly remembers Strehlow writing down the verse lines and listening carefully to the version being recorded. As Ken and Harold sang the song, they had apparently missed a line. Strehlow stopped them:

He said 'You two fellas just missed a line'. We started to sing another song. And when we started another one, then he called out, 'hey!'. And he was looking down at his paper. [Strehlow said,] 'You missed that one [line] hey?' 'You missed that one,' he said. 'Hey you bin ... why you bin miss that one?' he bin tell me. 'Oh we missed that one,' we bin tell him²7.

Harold laughed about the irony of the exchange. 'Was Strehlow right?' I asked. 'Had you in fact missed a line?' Shaking his head, Harold replied, 'Yewe yewe [yes, yes]. He was right. He's a singing bloke that one!'28

Having spent the first phase of his career largely dependent on written transcriptions of song and only beginning to make audio recordings of songs in the late 1940s, Strehlow's ear had been finely attuned. Paul Albrecht, a Lutheran pastor who, like Strehlow, is fluent in Western Arrernte and has made recordings of Anmatyerr song, has similarly testified to having seen Strehlow take down a song verse as he heard it for the first time. ${ }^{29}$ Strehlow's method in obtaining these recordings has never been closely analysed, however, it appears that he would listen to

26 See recordings SOU 00218: Tape No. 1, 1971, and Tape No. 2, 1971 (SOU 00219), at the Strehlow Research Centre, Alice Springs.

27 ibid.

28 ibid.

29 Paul Albrecht, personal communication to Jason Gibson, Adelaide, 3 July 2013. 
the songs before recording them and, as this audition was taking place, he would write down the verses as he heard them. Following this, the songs would be committed to tape. Tape was expensive at the time so presumably he thought it best to save tape space and simply document the song, without explanatory discussions. At the end of each verse it was common for Strehlow to either remind himself or check the contents of the next verse about to be sung. Describing his role in this process as a 'prompter' (Strehlow 1965: 60), he would give a cue to begin recording particular verses.

\section{The utility of the method}

A range of Central Australian Aboriginal people now commonly access the Strehlow collection. Many are looking for anthropological evidence to validate their associations with parcels of land within the Australian legal framework (Wilmot and Morgan 2010). Others, as Berndt (1979: 88) predicted, have turned to the Strehlow collection simply to 'find personal and social meaning and emotional stability in contemporary society'. Strehlow's immersion in the mainly Arandic languages, songs and ceremonies has produced a collection of great utility and value to researchers and Aboriginal people alike. This is not to suggest, as I hope some of the examples cited above have clearly demonstrated, that his body of work is without flaws, contradictions or omissions. On the contrary, the sheer volume and longevity of Strehlow's focused documentation have allowed ample opportunity for these limitations to come to the fore.

John Morton (1997) has also shown how Strehlow's model of land tenure, which stresses the autonomy of the anyenhenge (njinanga) section areas or estates, can be effectively challenged using some of Strehlow's own contradictory fieldwork data. Strehlow's work on 'regular and irregular marriages' also demonstrates the failures of conceptualising human activity with a social 'system' and inadvertently challenges some of Strehlow's own functionalist tendencies (Dousset 1999). Strehlow's genealogical records, too, were set down in a manner that allows for new readings. For example, when working in the western Anmatyerr communities in 1968, Strehlow encountered information that suggested that Anmatyerr practices of land and mythological inheritance were, in his view, anomalous-where children inherited their father's totemic centres and did not appear to 
have their own private conception totems. Although this practice sounded 'rather doubtful' to Strehlow, he decided to record exactly what he had been told:

[I]t is best to jot down what one is told instead of trying to 'tidy' up one's material. Genealogies are, after all the property of the heirs that figure in them; and what they know—or believe to know—must take precedence over the doubts and theories of the person who collects F.T.s [family trees].' (Strehlow 1968: 66)

Revealing his aversion for theoretical anthropology and his preference for a rather simplistic conception of pure ethnographic evidence, he writes that, 'in a hundred years' time future research scholars will be much more interested in knowing what' the Aboriginal informants 'had to say about their own traditions and institutions than in any explanatory theories advanced by Freud, Malinowski, Frazer, Róheim and the rest' (Strehlow 1971: xxxix). '[W] here local traditions are paramount and where myths, songs and ceremonies have always been regarded as private property', he argued, it was imperative that the anthropologist indicate clearly the names of his informants and the area for which that information is true' (Strehlow 1971: xxxii). The collection of detailed provenance data was therefore vital to understanding the interconnected webs of song verses, myths, ancestors, places and people that characterise Central Australian lifeworlds. It is this punctilious recording that facilitates current research into the Strehlow materials.

\section{Conclusion}

It was Strehlow's distinctive style of ethnography that led to his considerable achievements in anthropology, and the humanities more generally. Certainly, it was the intensive and particularistic documentation, as Ronald Berndt (1979: 88) notes, that offers so much to professional scholars and coming generations of Central Australians. Coming to his ethnographic practice from a perspective that privileged language and narrative led to an adoption of 'native concepts' and 'classifications' that were exceptional at the time. Moreover, this attention to song, religious belief and ritual led to an appreciation of the beauty and mystery of Central Australian lifeworlds, albeit often framed within Eurocentric comparisons and an undeniable primitivism. Strehlow's intellectual foundations ultimately 
led him towards a nostalgic search for rootedness (in geographically determined language regions) in opposition to abstracted theorisation or analysis.

It is this tension between classicism and social anthropology in Strehlow's work that gives it its singular character. In this sense, Strehlow's ethnography was an extremely significant forerunner to 'modernist Australianist ethnography' (Rumsey 2001: 20) that bridged artistic and anthropological perspectives. Anthropology, Strehlow (1966: 75) argued in the later stages of his career, ought to 'regain above all other things' its 'human view' where 'man' is put back into the 'Science of Man'. It is this descriptive approach to ethnography that makes both T. G. H. and Carl Strehlow's collections such valuable resources for researchers and Central Aboriginal people today.

What makes Strehlow's fieldwork data particularly interesting and useful to those now coming to this material is his particularistic approach to ethnographic documentation, his admission of contradictory data and the wideranging regional scope that reveals interconnections involving people, song and ritual repertoires across the landscape. What we might describe as the sociological or anthropological aspects of his work that elaborated 'models' or 'structures' of kinship, land tenure or social organisation were equally crucial in describing Arandic ontology. Much of this work, however, arose from Strehlow's methodological commitment to explicating the 'full details ... of every informant responsible for each piece of mythological and sociological information' (Strehlow 1971: xviii). This was imperative to interpreting the data from within a specifically Central Australian context.

Strehlow's diaries do not compartmentalise his experiences into different domains. His fieldwork experiences run seamlessly into personal reflection, mundane travel logistics, personal dalliances and, of course, thick ethnographic description. We might now wonder whether Strehlow respected phenomenology's critique of the division between social scientific inquiry and everyday experiences. I imagine he would have agreed with the intentions of the phenomenologists to seek direct understanding and indepth description (Jackson 1996: 2-7). Where Strehlow fails in this realm though is in his inability to acknowledge not only the dialogical origin of his data, but also the intercultural aspects of his work where Aboriginal 
men from varied backgrounds and experiences acted as co-producers in this collection. As a result, his ethnography is wilfully blind to the evidence of cultural continuity and ill equipped to theorise these issues.

The often backwards-looking frame of his romantic classicism prohibited any serious engagement with such notions. Strehlow's work, although interspersed with his personal musings, is almost devoid of any reflexive agonising about his ethnographic practice. The punctilious detail of his field collection, when coupled with the perspectives of Central Australian Aboriginal men, does, however, gives us scope to introduce these analyses. Strehlow's field diaries reveal someone deeply familiar with their anthropological subject but falling short of using these experiences to reflect critically on one's own assumptions or position. Collaborative rereadings of this archive with Anmatyerr and Arrernte people, while recognising the inescapable centrality of Strehlow 'the man' to the collection's production, give priority to the material itself. How and where this information-be it genealogies, song or film recordings-sits in its historical and cultural contexts is emphasised over and above the particular role of ethnographer or informant.

\section{References}

Anderson, C. (ed.). 1995. Politics of the secret. In Politics of the Secret, Oceania Monographs No. 45, pp. 1-14. Sydney: Oceania Publications.

Austin-Broos, D. J. 1997. On reading Theodor Strehlow's Agencies of Social Control in Central Australian Aboriginal Societies. Occasional Paper No. 1, pp. 51-6. Strehlow Research Centre, Alice Springs, NT.

Austin-Broos, D. J. 2004. Western Arrernte endogenous change and the impact of settlement. In Traditions in the Midst of Change: Communities, cultures and the Strehlow legacy in Central AustraliaProceedings of the Strehlow Conference, Alice Springs, 18-20 September 2002, (ed.) M. Cawthorn, pp. 60-5. Alice Springs, NT: Strehlow Research Centre.

Austin-Broos, D. J. 2009. Arrernte Present, Arrernte Past: Invasion, violence, and imagination in Indigenous Central Australia. Chicago: University of Chicago Press. 
Batty, P. 2013. 'Primitive Blacks Face White Man's Laws': The 1932 anthropological expedition to Mt Liebig, Central Australia'. In Recreating First Contact: Expeditions, anthropology, and popular culture, (eds) J. Bell, A. Brown and R. Gordon, pp. 197-239. Washington, DC: Smithsonian Institution Scholarly Press.

Beinssen-Hesse, S. 2004. Correspondence of Leo Frobenius and colleagues with Ekkehard Beinssen concerning proposed activities of the Frankfurt Institute for the Morphology of Culture in Australia. In The struggle for souls and science: Constructing the fifth continentGerman aries and scientists in Australia, Occasional Paper No. 3, (ed.) W. F. Veit, pp. 152-82. Strehlow Research Centre, Alice Springs, NT.

Berndt, R. M. 1979. T. G. H. Strehlow 1908-1978. Aboriginal History 3: 84-8.

Campbell, J. 1949. The Hero with a Thousand Faces. Princeton, NJ: Bollingen Foundation/Pantheon Press.

Campbell, J. 1974. The Mythic Image. Princeton, NJ: Princeton University Press.

Curran, G. 2011. The 'expanding domain' of Warlpiri initiation rituals. In Ethnography and the Production of Anthropological Knowledge: Essays in honour of Nicolas Peterson, (eds) Y. Musharbash and M. Barber, pp. 39-50. Canberra: ANU E Press.

Dobson, V. and Henderson, J. 1994. Eastern and Central Arrernte to English Dictionary. Alice Springs, NT: IAD Press.

Dousset, L. 1999. On reading Theodor Strehlow's Aranda Regular and Irregular Marriages', Occasional Paper No. 2, pp. 45-59. Strehlow Research Centre, Alice Springs, NT.

Fabian, J. 1983. Time and the Other: How anthropology makes its object. New York: Columbia University Press.

Freud, S. 1922. Totem und Tabu: Einige Übereinstimmungen im Seelenleben der Wilden und der Neurotiker. Leipzig: Internationaler Psychoanalytischer Verlag.

Geertz, C. 1961. Studies in peasant life: Community and society. Biennial Review of Anthropology 2: 1-41. 
Gibson, J. 2015. Central Australian songs: A history and reinterpretation of their distribution through the earliest recordings. Oceania 85(2): 165-82. doi.org/10.1002/ocea.5084.

Gillen, F. J., Mulvaney, D. J., Morphy, H. and Petch, A. 2001. 'My Dear Spencer: The letters of F. J. Gillen to Baldwin Spencer. Melbourne: Hyland House Publishing.

Gingrich, A. 2005. The German-speaking countries: Ruptures, schools and nontraditions-Reassessing the history of sociocultural anthropology in Germany. In One Discipline, Four Ways: British, German, French, and American anthropology, (eds) R. Parkin, S. Silverman and A. Gingrich with F. Barth, pp. 76-153. Chicago: University of Chicago Press.

Gray, G. G. 2007. A Cautious Silence: The politics of Australian anthropology. Canberra: Aboriginal Studies Press.

Green, J. 2010. Central and Eastern Anmatyerr to English Dictionary. Alice Springs, NT: IAD Press.

Green, J. A. 2001. 'Both sides of the bitumen': Ken Hale remembering 1959. In Forty Years On: Ken Hale and Australian languages, (eds) J. Simpson, D. Nash, M. Laughren, P. Austin and B. Alpher, pp. 29-43. Canberra: Pacific Linguistics.

Hale, K. 1962. Internal relationships in Arandic of Central Australia. In Some Linguistic Types in Australia. Part 2, (ed.) A. Capell, pp. 171-83. Oceania Linguistic Monographs. Sydney: University of Sydney.

Hedican, E. 2009. Ways of knowing in anthropology: Alexandre Chayanov and the perils of 'dutiful empiricism'. History and Anthropology 20(4): 419-33. doi.org/10.1080/02757200903219621.

Hill, B. 2002. Broken Song: T. G. H. Strehlow and Aboriginal possession. Sydney: Random House.

Hinkson, M. and Beckett, J. 2008. An Appreciation of Difference: W. E. H. Stanner and Aboriginal Australia. Canberra: Aboriginal Studies Press.

Jackson, M. 1996. Introduction: Phenomenology, radical empiricism, and anthropological critique. In Things As They Are: New directions in phenomenological anthropology, (ed.) M. Jackson, pp. 1-50. Bloomington: Indiana University Press. doi.org/10.1007/978-1-34913729-9_1. 
Jackson, M. 2003. Broken Song: T. G. H. Strehlow and Aboriginal possession. [Book review.] Australian Aboriginal Studies (1): 88-9.

Jones, P. 1995. Norman B. Tindale: An obituary. Records of the South Australian Museum 28(2): 159-76.

Jones, P. 2004. A maverick and his mentors. In Traditions in the Midst of Change: Communities, cultures and the Strehlow legacy in Central Australia-Proceedings of the Strehlow Conference, Alice Springs, 18-20 September 2002, (ed.) M. Cawthorn, pp. 36-41. Alice Springs, NT: Strehlow Research Centre.

Jorgensen, D. 2010. Simulating the sacred in Theodore Strehlow's 'Songs of Central Australia'. The Bible and Critical Theory 6(2): 22.2-22.10.

Kaiser, S. 2002. The Stern case. In Traditions in the Midst of Change: Communities, cultures and the Strehlow legacy in Central AustraliaProceedings of the Strehlow Conference, Alice Springs, 18-20 September 2002, (ed.) M. Cawthorn, p. 205. Alice Springs, NT: Strehlow Research Centre.

Kenny, A. 2004. Western Arrernte Pmere Kwetethe spirits. Oceania 74(4): 276-89. doi.org/10.1002/j.1834-4461.2004.tb02855.x.

Kenny, A. 2013. The Aranda's Pepa: An introduction to Carl Strehlow's masterpiece Die Aranda- und Loritja-Stämme in Zentral-Australien (1907-1920). Canberra: ANU E Press.

Koch, H. 2006. The Arandic subgroup of Australian languages. In Australian Languages: Classification and the comparative method, (eds) C. Bowren and H. Koch, pp. 127-50. Amsterdam: John Benjamins Publishing Company.

McNally, W. 1981. Aborigines, Artefacts, and Anguish. Adelaide: Lutheran Publishing House.

Marcus, J. 2001. The Indomitable Miss Pink: A life in anthropology. Sydney: UNSW Press.

Mills, C. W. 2000. The Sociological Imagination. New York: Oxford University Press. 
Moore, D. 2003. T. G. H. Strehlow and the linguistic landscape of Australia 1930-60. Honours thesis, University of New England, Armidale, NSW.

Moore, D. 2008. T. G. H. Strehlow and the linguistic landscape of Australia 1930-1960. In Encountering Aboriginal Languages: Studies in the history of Australian linguistics, (ed.) W. McGregor, pp. 273-300. Canberra: Pacific Linguistics.

Morton, J. 1993. Romancing the stones. Arena Magazine (April-May) (4): 39-40.

Morton, J. 1995. 'Secrets of the Arandas': T. G. H. Strehlow and the course of revelation. In Politics of the Secret, Oceania Monograph No. 45, (ed.) C. Anderson, pp. 51-66. Sydney: Oceania Publications.

Morton, J. 1997. Arrernte (Aranda) land tenure: An evaluation of the Strehlow model. Occasional Paper No. 1, pp. 107-26. Strehlow Research Centre, Alice Springs, NT.

Morton, J. 2004. Krippendorf's lesson in the centre: The shaping of the Arrernte through T. G. H. Strehlow's 'Family romance'. In Traditions in the Midst of Change: Communities, cultures and the Strehlow legacy in Central Australia - Proceedings of the Strehlow Conference, Alice Springs, 18-20 September 2002, (ed.) M. Cawthorn, pp. 42-7. Alice Springs, NT: Strehlow Research Centre.

Peterson, N. 2000. An expanding Aboriginal domain: Mobility and the initiation journey. Oceania 70(3): 205-18. doi.org/10.1002/j.18344461.2000.tb03019.x.

Róheim, G. 1925. Australian Totemism: A psycho-analytic study in anthropology. London: George Allen \& Unwin.

Róheim, G. 1932. Psychoanalysis of primitive cultural types. International Journal of Psycho-Analysis 13: 1-224.

Rowse, T. 1992. Strehlow's strap: Functionalism and historicism in a colonial ethnography. Journal of Australian Studies 16(35): 88-103. doi.org/10.1080/14443059209387120. 
Rumsey, A. 2001. Tracks, traces and links to land in Aboriginal Australia, New Guinea, and beyond. In Emplaced Myth: Space, narrative, and knowledge in Aboriginal Australia and Papua New Guinea, (eds) A. Rumsey and J. Weiner, pp. 19-42. Honolulu: University of Hawai' $i$ Press.

Schuster, M., Haberland, E., Straube, H. and Jensen, A. E. 1964. Festschrift fur Ad. E. Jensen/herausgegeben von Eike Haberland, Meinhard Schuster und Helmut Straube. Munich: Klaus Renner Verlag.

Smith, R. 2009. 'Stuff at the core of land rights claims': The Strehlow collection. Journal of Northern Territory History 20: 75-93.

Starn, O. 2011. Here come the anthros (again): The strange marriage of anthropology and native America. Cultural Anthropology 26(2): 179-204. doi.org/10.1111/j.1548-1360.2011.01094.x.

Strehlow, T. G. H. 1932. Book I: Field diary (1)1932, Strehlow Research Centre, Alice Springs, NT.

Strehlow, T. G. H. 1942. Aranda phonetics. Oceania 12(3): 255-302. doi.org/10.1002/j.1834-4461.1942.tb00360.x.

Strehlow, T. G. H. 1947. Aranda Traditions. 2nd edn. New York: Johnson Reprint.

Strehlow, T. G. H. 1950. London diary 1(b), Strehlow Research Centre, Alice Springs, NT.

Strehlow, T. G. H. 1952. London diary 3(1951-52), Strehow Research Centre, Alice Springs, NT.

Strehlow, T. G. H. 1953. Book XVIII: Field diary and myths 18(1953), Strehow Research Centre, Alice Springs, NT.

Strehlow, T. G. H. 1956. Friendship with South-East Asia: A cultural approach. Melbourne: Riall Bros.

Strehlow, T. G. H. 1964a. Book XXXII: Field diary (32)1964, Strehlow Research Centre, Alice Springs, NT.

Strehlow, T. G. H. 1964b. Book XXXIII: Field diary (33)1964, Strehlow Research Centre, Alice Springs, NT. 
Strehlow, T. G. H. 1965. Book XXXVI: Field diary (36)1965, Strehlow Research Centre, Alice Springs, NT.

Strehlow, T. G. H. 1966. Relative Relatives. [Review.] Australian Book Review 5(4): 74-5.

Strehlow, T. G. H. 1968. Book XXVIII: Field dairy (38)1968, Strehlow Research Centre, Alice Springs, NT.

Strehlow, T. G. H. 1969. Ayers Rock and Winbaraku by C. P. Mountford: A critical examination. The Strehlow Research Foundation 11-15(2).

Strehlow, T. G. H. 1970a. Fortschritt Ins Nichts. [Review.] Journal of the Australasian Universities Modern Languages Association (3): 365-6.

Strehlow, T. G. H. 1970b. Geography and the totemic landscape in Central Australia: A functional study. In Australian Aboriginal Anthropology: Modern studies in the social anthropology of the Australian Aborigines, (ed.) R. M. Berndt, pp. 93-140. Perth: University of Western Australia Press.

Strehlow, T. G. H. 1971. Songs of Central Australia. Sydney: Angus \& Robertson.

Strehlow, T. G. H. 1997 [1950]. Agencies of social control in Central Australian Aboriginal societies. Occasional Paper No. 1, pp. 1-51. Strehlow Research Centre, Alice Springs, NT.

Sutton, P. 2003. Native Title in Australia: An ethnographic perspective. Melbourne: Cambridge University Press. doi.org/10.1017/ CBO9780511481635.

Wilmot, H. and Morgan, R. 2010. Written proof: The appropriation of genealogical records in contemporary Arrernte society. Land, Rights, Laws: Issues of Native Title 4(5). 
This text is taken from German Ethnography in Australia, edited by Nicolas Peterson and Anna Kenny, published 2017 by ANU Press, The Australian National University, Canberra, Australia.

dx.doi.org/10.22459/GEA.09.2017.10 